Jihan Aqil Rihhadatul 'Aisy ${ }^{1}$ and Moses Glorino Rumambo Pandin ${ }^{2}$

Universitas Airlangga

Jl. Airlangga No.4-6, Airlangga, Kec. Gubeng, Kota Surabaya, Jawa Timur 60115

jihan.aqil.rihhadatul-2020@ fib.unair.ac.id and moses.glorino@fib.ac.id

\title{
BOOK REVIEW: \\ All About National Insights in Context: Democracy, Citizenship, Social Integration (Serba-Serbi Wawasan Kebangsaan dalam Konteks: Demokrasi, Kewarganegaraan, hingga Integrasi Sosial)
}

Yuniar Mujiwati; Pasuruan; 2020; ISBN 978-623-95025-4-6; xi + 236 pages

\section{INTRODUCTION}

The science of citizenship is a crucial thing that must be present at every level of education, where the aim for citizens is to make them be able to think or to have a foundation of nationalism and patriotism that must be nurtured from an early age. It was written with the hope of strengthening the competence of students or the public in terms of knowledge and attitudes as a whole, where the process of achievement is through learning from several materials arranged in a continuous unit. The achievement of competence can be applied to the present and future life of the nation. This book provides useful information to increase national insight in the context of democracy, citizenship, and even social integration.

This masterpiece provides an understanding about national insight or insight into the archipelago in the context of democracy, citizenship to social integration. The insight of the archipelago is a teaching's belief about Indonesian people with the aim that there is no misleading or deviation in achieving and realizing national ideals and goals. Thus, the insight of the archipelago can become a vision foundation in carrying out national life in which basic things like this should be understood by the public (Indonesian people), especially students as agents of change. The book certainly needs to be reviewed so that readers can find a brief synopsis of the book or a reviewer's assessment of this work which can be used as a consideration before reading it in its entirety. In a review, a reader can find out what urgency they have, so they are strongly advised to join in reading the book.

Information or material on state issues that have emerged for a long time also presented in this writing. If you look at the current conditions, the rate of globalization is growing rapidly. Indonesian citizens must be aware of or anticipate the threats that arise from the science and technology sector. This book comes with material that explains the development of science and technology which might cause a problem for our nation. But the book also comes with the ways to deal with the impact of its development on the Republic of Indonesia. It can be used as a reminder for the Indonesian people not to be complacent about the convenience presented by technological sophistication.

The essence of citizens in a democratic system is citizens who have the same rights and obligations and are not differentiated between races and ethnic groups. The Indonesian 
democratic system is Pancasila democracy, the source of which is the personality and sociocultural values of the nation, especially those contained in the 4th Pancasila Principle. Pancasila democracy is the embodiment of the fourth principle of Pancasila, which states that the implementation of Pancasila Democracy is the embodiment of the fourth principle, namely stating that the implementation of this democracy reflects the values of Pancasila. On the other hand, principle, rights and obligations are always related to one another. Someone who gets their rights must first carry out their obligations. Vice versa, someone who has carried out his obligations has the right to receive his rights.

\section{REVIEW}

This book meets the needs of the audience which the material was written is following the problems that are often faced at this time. Information is arranged in such a way to add insight to readers regarding matters relating to the life of the nation and state. The book has quite complete information and it's also suitable as a complement if the reader is a student who wants to know more about this kind of subject. In other words, this writing can add or enrich readers' insights about national issues and respond to national issues that exist around them.

In general, books with the major theme of citizenship or Pancasila only focus on issues such as human rights, democracy, national integration, or similar matters, the book with the title "SerbaSerbi Wawasan Kebangsaan dalam Konteks: Demokrasi, Kewarganegaraan, hingga Integrasi Sosial" added a material that discusses the development of science and technology for the Republic of Indonesia. Not only describes the positive impact of the development of science and technology on the survival of the nation and state, but this writing also describes ways to deal with the negative effects of advances in science and technology, such as instilling an attitude of responsibility and selectivity. (P. 218-229).

This masterpiece can provide insight to readers about the importance of a citizen having a nationalist and patriotic spirit based on the understanding of archipelago insights and other supporting matters such as material about diversity. It is written that diversity is a national reality that cannot be denied, its existence encouraging the creation of peace in the life of the nation and state. (P.90).

As the author hopes, it can be used as a fertilizer to increases the sense of nationalism and patriotism of every citizen. The community will have a high sense of love for the nation if they know or learn more about what things to anticipate or what things can cause a damage to their nation so that a mutual awareness emerges to mutually maintain the unity and integrity of the nation.

The book provides definitions of a term based on expert opinion. Of course, this is very good so the readers can understand various meanings from every given point of view. Not only does it stop at the opinion of experts for a term, but this work also presents the legal basis of a conception. Factors and backgrounds are also added as a compliment so that readers can understand a concept as a whole. 
The information inside is very convincing because it includes sources of opinions or written statements. One example is this book regarding the legal sources of the archipelago insight that are accepted as the political concept of citizenship as stated in the rules: a) Tap MPR. No. IV/MPR/1973 on 22nd March 1973, b) Tap MPR. No IV/1978/22/March/1978/ GBHN, c) Tap MPR. No. II/MPR/1983/12/March/1983. (P.33).

Another piece of evidence that shows the book is convincing exists in the sub-chapter entitled State Life in the Concept of the Unitary State of the Republic of Indonesia (NKRI). In this chapter, various statements are written following the articles in the Constitution. An example is Article 1 paragraph (1) of the 1945 Constitution of the Republic of Indonesia which is the original text containing the principle that "the State of Indonesia is a unitary state, which shapes is the Republic." (P.64). Another example that shows it provides statements based on reliable sources is a statement of the spirit for Indonesia to be united, both as stated in the preamble and the articles directly in the five articles, namely: article 1 paragraph (1). Article paragraph (1), article 18B paragraph (2), article 25A, and article 37 paragraph (5) of the 1945 Constitution of the Republic of Indonesia as well as the formulation of articles that confirm the Unitary State of the Republic of Indonesia, and the existence of institutions in the Law of the Republic of Indonesia in 1945. The principle of unity within the Republic of Indonesia is emphasized in paragraph Fourth Preamble to the Constitution of the Republic of Indonesia year1945, namely "... to form a Government of the Indonesian state that protects the entire Indonesian nation and all Indonesian bloodshed". (P.65).

The book was written and arranged in such a way, so that it looks pleasant to read. The language used is easy to understand. The writing order is straightforward. The written explanation is concise but sufficient to explain the problem at hand. The size of this work is relatively small, making it easy for readers to carry it while traveling. The writing that is published per page can also be said to be a little bit so that it makes the reader curious about the continuation of the discussion and can also end up reading it as a whole because it is not boring.

The material contained in this writing is complete and comprehensive. The ideas generally described in a book on the theme of citizenship are also discussed in this work, of course, in a language that is very easy to understand. The author also does not forget to add the most relevant issues to the current era, namely a threat to the life of the nation and state originating from science and technology.

The language used is quite easy to understand, the discussion is clear and not long-winded, 1 material is summarized in a good way so that readers can immediately understand the essence of the topic being discussed, this writing can also be used as a complement book in learning or understanding things - matters relating to Pancasila or citizenship.

This work measures $14.8 \times 21 \mathrm{~cm}$ (A5) which is quite small. For young people, the size of the book is suitable and comfortable if you want to carry it everywhere but it will be a little difficult 
for older readers because the words contained inside are too small. Overall, there are no significant drawbacks.

The language use and substances are very good and follow the author's goals. Maybe for the next or future book, the cover design can be more attractive following the times, so it looks eyecatching. The size of the book can be considered to make it bigger so that readers of all ages can be more comfortable reading it.

\section{Jihan Aqil Rihhadatul 'Aisy ${ }^{1}$ dan Moses Glorino Rumambo Pandin² Universitas Airlangga}

\section{REFERENCE}

Mujiwati, Y. (2020). Serba-Serbi Wawasan Kebangsaan dalam Konteks; Demokrasi, Kewarganegaraan, hingga Integrasi Sosial. Pasuruan: Lembaga Academic \& Research Institute.

\section{AUTHOR SHORT BIOGRAPHY}

Yuniar Mujiwati, M.Pd is a lecturer with specific expertise in Pancasila and civics education. Some of her best works are dedicated to deepening education, cultivating patriotism and nationalism, as well as community service. The lecturer who currently also serves as the Head of the Pancasila and Citizenship Education Program at PGRI Wiranegara University is also actively inviting his students to work together in various scientific journal publications. With this, she hopes that one day her students and lecturers in her study program will also be proud because they have many intellectual works that can be consumed by the public. 